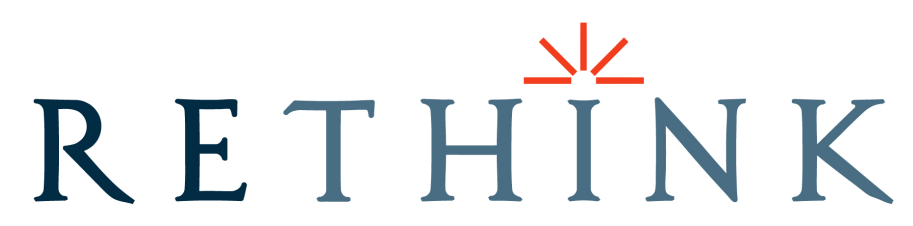

INSTITUTE WASHINGTON DC 


\section{RELIGIOUS RADICALISM IN CENTRAL ASIA}

GALYM ZHUSSIPBEK

RETHINK PAPER 12

September 2013

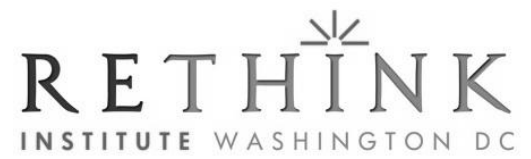


The Rethink Institute is an independent, not-for-profit, nonpartisan research institution devoted to deepen our understanding of contemporary political and cultural challenges facing communities and societies around the world, in realizing peace and justice, broadly defined.

The Institute pursues this mission by facilitating research on public policies and civic initiatives centering on dispute resolution, peace building, dialogue development, and education. Toward these goals, the Institute sponsors rigorous research and analysis, supports visiting scholar programs, and organizes workshops and conferences.

(C) Rethink Institute. All rights reserved

ISBN: 978-1-938300-14-1

Printed in the USA

Rethink Institute

750 First St., NE, Suite 1125

Washington, DC 20002

Phone: (202) 842-2026

Fax: (202) 747-7637

info@rethinkinstitute.org

This publication can be downloaded at no cost at www.rethinkinstitute.org 


\section{CONTENTS}

1 Summary

3 Introduction

$4 \quad$ Early Political Islam and Radicalism in Central Asia

6 Threats Posed by Literalist Perceptions of Islam

$8 \quad$ Antidote to Literalism

8 The Rise of Religious Radicalism in Kazakhstan and Kyrgyzstan

11 Kazakhstan's Recently Adopted Anti-Radicalism Policy

14 Conclusions and Recommendations

17 Appendix: Summary of the Kazakhstan's "Law on Religious Activity and Religious Associations" (11 October 2011)

20 About the Author 



\section{Summary}

Islam has assumed a decisive role in Central Asia since the collapse of the Soviet system. However, the religious comeback has produced adverse effects, particularly the rise of religious radicalism. The Hanafi School, the main conventional school of Islamic interpretation in Central Asia, which greatly contributed to the Islamic underpinnings of Central Asian nomadic and settled Islamic civilization, employs a rational approach and cherishes local customs and traditions. However, the narrow, literal perceptions of Islam lack these features and render Islam a static, frozen system of teachings. Those literalist perceptions of Islam constitute the ontological and intellectual foundation of radicalism in the world, in general, and in contemporary Central Asia, in particular.

Religious literalism flourishes in Muslim communities that lack vibrant intellectual life and dynamic religious education. Despite the decadeslong systematic and forceful anti-religious campaign during Soviet rule, Central Asian Muslims consider themselves no less Muslims than others. However, the region has been seriously deprived of a formal Islamic education system and Islamic intellectual life. Consequently, at the time of independence the Central Asian Muslim community was characterized by a ubiquitously low level of Islamic education, 'broken tradition,' and concomitant 'shaken identity', all of which gave rise to distorted and radical understandings of Islam. The abrupt politicization of post-Soviet Muslims in the early 1990s led to the instrumentalization of Islam in politics, which produced disastrous results in Uzbekistan and Tajikistan.

In recent years, Kazakhstan and Kyrgyzstan embarked on comprehensive anti-terrorist activities and adopted complex measures at the official level in fighting radical (depicted as "non-traditional") interpretations of Islam, since the very liberal attitude of these countries towards all religious groups, which had been adopted earlier, and the lack of state support to the Muftiyat (the civil society body representing the Hanafi Muslims) led to the active penetration of radical religious groups and ideas into their societies. Despite all its merits, however, tightened control over religious organizations and 'semi-official' support of the conventional Hanafi interpretation of Islam - indispensable to preserve peace, stability and the future of civil society in both countries - should be considered a temporary policy. There are no substantial reasons to regard the recent policy shift in Kazakhstan and Kyrgyzstan as a precursor to 'assertive/combative secularism' in and establishment of a 'state religion', not to mention securitization of Islam. 


\section{Introduction}

After the collapse of the Soviet system, which was hostile to religion, Islam turned into a significant element of identity, especially for Central Asian youth. The level of religiosity increases every year. However, along with religious revival came threats of radicalism and terrorism. Since the early 1990s, moderate interpretations of Islam, which are mainly based on the classic school or methodology of Sunni Islam, have been undermined by the spread of radical ideas in the region. Nowadays religious radicalism poses a significant threat to all countries in the region. Moreover, in recent years, a merging of a 'post-Soviet criminal mind-set' and radical religious interpretations can be observed in the region. Although 'ordinary' criminalization plagued Central Asian societies in the 1990s in parallel with the dissolution of the Soviet system and its

After the collapse of the Soviet system, which was hostile to religion, Islam turned into a significant element of identity, especially for Central Asian youth. The level of religiosity increases every year. However, along with religious revival came threats of radicalism and terrorism. institutions, the latest wave of the criminalization syndrome in Central Asia features radical religious discourse, which had previously emerged in the North Caucasus and Tatarstan regions of the Russian Federation.

Radical religious interpretations began spreading in parts of Central Asia at different times. While radicalism emerged in some regions of Uzbekistan and Tajikistan as early as the first half of the 1990s among some local 'Islamic leaders,' it emerged in Kazakhstan and Kyrgyzstan, especially in the 2000s, with the return of foreign educated (predominantly in some Gulf states) theology students, influencing young people of different social and ethnic backgrounds. Also, since 2009-2010, radical groups from other regions (especially of North Caucasian origin) have built connections with some of their 'brethren' in Kazakhstan and some members of the Central Asian criminal underground.

The issue is vital since, today, religion is back in Central Asia. Consequently, the role played by Islam in the personal as well social life of Central Asians, regardless of their ethnicity and nationality, has increased considerably and will increase further in future. 


\section{Early Political Islam and Radicalism in Central Asia}

After the fall of the Soviet Union, Muslims of Central Asia found themselves in a paradoxical situation: on the one hand, the former atheistic totalitarian regime had died and the gates of liberty were opened unexpectedly, leading to euphoria; on the other hand, the heavy legacy of the Soviet period and the 'shaken identity' it left for the postSoviet Muslim community was felt more strongly than ever. The Soviet regime was hostile and aggressive towards religions, especially Islam. During the Soviet period, 'high Islam' was almost completely destroyed: intellectual platforms of Islam disappeared; 'ulema' (Muslim scholars

During the Soviet period, 'high Islam' was almost completely destroyed: intellectual platforms of Islam disappeared; 'ulema' (Muslim scholars trained in classic Islamic educational and spiritual system) was nearly totally

exterminated; and the classic Islamic

educational system based on classic methodology of the Hanafi school came to the brink of extinction. trained in classic Islamic educational and spiritual system) was nearly totally exterminated; ${ }^{1}$ and the classic Islamic educational system based on classic methodology of the Hanafi school came to the brink of extinction. As a result, Islamic Central Asian civilization whether of nomadic or settled origin and the Central Asian Muslim identity have drastically eroded. In sum, after three generations of Soviet social engineering, by the early 1990s, Central Asian Muslim communities were almost entirely at a very low level of religious education and could be characterized as the most dramatic example of postatheistic societies.

Despite the 'broken tradition' and 'religious minimalism' caused by a decades-long systematic and forceful anti-religious campaign, however, "Central Asians consider themselves no less Muslims."2 Central Asian Muslims felt great reverence for the religion of their forefathers, and in the climate of deep political, economic and social crises coupled with the ideological and ideational vacuum produced by the collapse of the official ideology, some Central Asian Muslims began embracing Islam as the sole alternative to communism or any other political system or ideology, thus opening up

\footnotetext{
1 The fragmented Islamic education kept by the Soviet regime in some places (primarily in Bukhara) was designed to serve the interests of the Soviet system.

2 Khalid, Adeep, 2007. Islam After Communism: Islam and Politics in Central Asia.

Berkeley: University of California Press, pp. 121-122
} 
the way for instrumentalization of Islam in politics and downgrading it to the level of a political ideology. This tendency led to the emergence of a phenomenon, which can be termed 'early Political Islam,' leading to disastrous results in post-atheistic and post-Soviet Central Asia.

The ideational base of many Muslim organizations and movements "was heavily influenced by the atmosphere of politicization of the late Soviet years and the first years of independence". ${ }^{3}$ Even the Islamic concept of 'dawah' (mission) "does not necessarily embrace the propaganda of Islam or Islamic values'... the concept was used 'to convey an even more political message". ${ }^{4}$ Some Muslim activists began openly challenging the political power holders and some groups were engaged in violent acts. ${ }^{5}$ Subsequently in Uzbekistan, the link between political violence and radical teachings formed rapidly, and afterwards radical groups were declared the primary security issue. On the other hand, in the course of the 1990s in some other places in the former Soviet Union, such as Chechnya, Islam was instrumentalized as a tool for national selfdetermination in the fight against Russian domination.

Religiously-motivated militancy and violence as such did not affect Kazakhstan and Kyrgyzstan ${ }^{6}$ until recently. However, after 2010, Kazakhstan and Kyrgyzstan - the relatively most liberal states in religious affairs among countries in the region - also embarked on comprehensive anti-terrorism activities and adopted measures to fight radical (depicted as "non-traditional") interpretations of Islam.

Last but not least, the criminalization process has contributed to a degree to the rise of extremism among Central Asian Muslims. In the late 1980s and the first half of the 1990s, the post-Soviet states experienced an upsurge of criminalization which was catalyzed by the sociological peculiarities of societies in transition, such as the popularity of the criminal subculture and legal relativism. In such an atmosphere, the post-Soviet criminal mind-set was able to penetrate into the Islamic praxis of some Muslims. What is extremely alarming is that a significant number of such people can be found among hard-line radicals. Moreover, most recently, although limited but nonetheless observable,

\footnotetext{
3 Olcott, Martha Brill, 2007. Roots of Radical Islam in Central Asia , Carnegie Papers, Number 77, p.28

4 Olcott, p. 28

${ }^{5}$ Interview by the author of a student of Dagestan origin who attended religious school in Namangan city and students of Uzbek origin who attended various religious schools in the Fergana region.

6 The radical groups in Kyrgyzstan in the 1990s did not target the Kyrgyz government, as they just used the territory to cross to Uzbekistan.
} 
an unexpected symbiosis between some radical groups and some criminal groups in Kazakhstan and Kyrgyzstan has been formed. ${ }^{7}$

\section{Threats Posed by Literalist Perceptions of Islam}

Many in academia and the media employ concepts such as fundamentalism, (neo)Wahhabism or (neo)Salafism to denote religious radicalism. It is better and more explanatory to use the concepts 'literalism' and 'literalists,' which more or less underlie the methodology behind radical teachings and demonstrate the logic that lies at the root of the problem.

The literalist approach and methodology, in contrast to the dynamic conventional approach, tend to be exclusivist, legalistic and indifferent to the general spirit of religious teaching and the wholeness of context.

Literalists have very simplistic and rigid understanding of the principles of

Literal understanding and perceptions of Islam constitute the intellectual background of almost all extremist and radical interpretations of Islam in the contemporary world.

first, the 'general' category - pertaining to every time and forming the Islamic world-view (such as "there is no compulsion in religion" or "peace is better") and second, the 'occasional' category - pertaining to particular situations, such as those which are about self-defense activities with a particular group of people.

Literal understanding and perceptions of Islam constitute the intellectual background of almost all extremist and radical interpretations of Islam in the contemporary world. However, it would be incorrect and an oversimplification to argue that every Muslim who embraces the literal methodology of understanding texts is an extremist or, much worse, a terrorist. Nonetheless, under existing circumstances (first, there is so much provocative information instigating negative

\footnotetext{
${ }^{7}$ Interview by the author of imams serving in troubled regions.
} 
emotions, especially among young Muslims; second, as a result of political, social and intellectual crises and armed conflicts in many Muslim societies, there are a number of young people having embraced Islam with already traumatized psychology) these kinds of believers can be easily manipulated to follow radical preachers and even to be engaged in illegal, violent activities because they lack the ability to understand religious teachings in holiness, and their perceptions of the world tend to be strictly dualistic, dividing the outside world into 'black and white.'

Literalists are inclined to perceive the outside world as divided into the rigid categories 'us versus them', employing the concepts 'Dar al-harb (the world of nonbelievers) and 'Dar al-Islam' (the world of Islam). However, these concepts cannot be found in the Quran and Sunnah, and they do not indicate the conventional Islamic perception of the world. These concepts were introduced by Islamic lawyers regarding particular conditions existent in premodern times, hence they are subject to reinterpretation, especially by those Muslims who live in democratic societies and enjoy their rights of freedom of conscience and freedom of religion.

It is necessary to point out that according to an orthodox understanding of Islam (as it is stressed by classical Sunni scholars), Islam not only does not prioritize the establishment of an Islamic state, but Islamic sources also do not offer a certain type or detailed structure of a particular 'Islamic' political system or regime; there are only some general guidelines pertaining to the well-established principles of justice, power sharing, the rule of law, and etc.

It is worth mentioning that the literalist understanding of 'being Muslim' tends to be very narrow. Some literalists want to reeducate all other Muslims in the spirit of their understanding of 'pure Islam,' as they do not regard Muslims who do not share their views as 'real Muslims.' 'Takfirists' - the most radical among the 'literalists' (adhering to the 'takfirism' doctrine), - falsely believe that all other Muslims must be exterminated. Takfirists accuse all other Muslims of unbelief ('kufr') and apostasy ('ridda'), thus labeling them unbelievers ('kafir') and apostates ('murtad'). They reject any compromise with other Muslims who do not shared their views and agitate for armed jihad against the government. The doctrine of 'takfir' legitimizes disobedience and revolt against the government, whether it is held by Muslims or not, because the doctrine says that any ruler, regardless of his identity and practice (and society at 
large), if he does not follow takfiri radicals' views, must be rejected and opposed by force. ${ }^{8}$

\section{Antidote to Literalism}

Since the effect of secular and liberal ideas is limited in taming religious radicalism, proper religious teachings and education appear to be the only antidote. Muslims have a special responsibility to challenge radical Muslims and neutralize them. ${ }^{9}$ This can be done only if proper interpretations of Islam based upon tolerance, inclusiveness, and high morals are revitalized and spread through dynamic religious education. In Central Asia, the dynamism of Islam is best exemplified by classical Hanafi school teachings. Hanafi was the main school of interpretation of Islamic sources for a millennium in Central Asia until the Soviet period, and had penetrated both settled and nomadic Central Asian civilization. Historically, Central Asia was one of the leading intellectual and spiritual centers of Islamic civilization, nourished by Hanafi teachings.

The Hanafi School's main doctrine is based upon a rational search for a solution to a particular issue that does not have any direct answer in primary Islamic sources, while cherishing local cultures, traditions, and community cohesion as well putting emphasis on building mutual understanding among different groups of people. The significance of this methodology lies first in producing a religious and logical counterbalance to all kinds of literal, particularly radical, perceptions of Islam, and second in nourishing good manners, especially tolerance and high morals, among Muslims. It is no surprise that radical groups that have penetrated the region since the 1990s regard Hanafi doctrine and methodology as their biggest adversary, more so than atheists and unbelievers.

\section{The Rise of Religious Radicalism in Kazakhstan and Kyrgyzstan}

As mentioned above, Kazakhstan and Kyrgyzstan became the objects of threats of radicalism relatively recently. Although the activities of radical groups were detected much earlier, radicalism-motivated terrorism did not affect Kazakhstan directly until 2010 when a series of terrorist acts

\footnotetext{
${ }^{8}$ Noorhaidi, Laskar. Jihad, Islam, Militancy and the Quest for Identity in Post-New Order Indonesia, PhD Dissertation, International Institute for Asian Studies (IIAS), Leiden, p.147; Ilmihal (Sunni Islam Catechism), Ankara: Diyanet Isleri Baskanligi, Vol.1, http://www.diyanet.gov.tr/turkish/basiliyayin/ilmihal.pdf, p.29

9 Bacik, Gokhan, "The unwanted truth: the Muslim enemies of Islam", Todays Zaman, 03 February 2013, http://www.todayszaman.com/columnist-305995-the-unwanted-truththe-muslim-enemies-of-islam.html
} 
were perpetrated by radicals/radical groups. As a response, the Kazakh government adopted a new law regulating the sphere of religion and other legal acts tightening state control over religious organizations. Also some 'preferences' were made regarding 'traditional' religious beliefs. Kyrgyzstan adopted a new law imposing more strict requirements for functioning of religious organizations in 2008. The Kyrgyz Agency for Religious Affairs adopted a special 'strategy of state policy' in the field of religion for the period 2009-2015, giving special priority to cooperation with the Hanafi Muslim community of the country. ${ }^{10}$

In contrast to such developments, the earlier policies of both states were quite liberal. In January 1992, a month after its independence, Kazakhstan enacted a liberal law regulating the functioning of religious organizations. This liberal approach contributed significantly to the revival of religious life in the country. Nevertheless, over time radical literalist groups and a number of violent sects rushed into the country and began influencing large parts of society. Muslim communities in Kazakhstan and Kyrgyzstan were faced with considerable schism when some literalists, after having gained a considerable number of supporters among local Muslims, began openly denouncing the Hanafi imams of Muftiyat-controlled mosques, accusing them of having 'gone astray,' even of being apostate and collaborating with the enemies of Islam. Moreover, as these people reject almost all local traditions, serious cleavages have emerged in many villages, among relatives, and in neighborhoods. In some regions literalists were able to succeed in gaining popularity and reorienting a majority of local mosques' congregations. ${ }^{11}$ Consequently, in recent years in Kyrgyzstan, the ideational confrontation between literalists and 'traditionalists' (adherents of the Hanafi School) have worsened and serious cleavages have emerged in the Muslim community. ${ }^{12}$ Many Kazakh experts have

\footnotetext{
10 For information, visit the official site of the Commission on Religious Affairs under the President of Kyrgyz Republic, http://religion.gov.kg/laws

11 Interview by the author of the lecturers of Nur-Mubarak Islamic University and Madrasah opened by the Kazakhstan Muftiyat. They lamented that in Western Kazakhstan 'literalist' preachers could influence a large segment of attendants of the local mosques, e.g., in one of the central mosques of the region nearly $90 \%$ of the congregation started following a 'literalist preacher' but not the Hanafi imams of their mosque.

12 Malikov, Kadir, "Central Asia faces with tremendous challenges and threats", 29 April 2013, http://www.islamsng.com/authors/Malikov/6772; Malikov, Kadir, "State does not pay enough attention to religious education", 4 July 2013, http://catoday.org/centrasia/kgru/9215-gosudarstvo-ne-obraschaet-dolzhnogovnimaniya-na-religioznoe-obrazovanie-ekspert.html
} 
also been warning about serious splits among Muslims of the country along the lines 'literalists' and 'traditionalists.' 13

There are many reasons for successful penetration of literalist Muslim groups in Kazakhstan and Kyrgyzstan. The leading reason is lack of a developed and dynamic religious education system and lack of proper information about Islam. Radical Muslims in post-Soviet Central Asia at the very beginning were faced with information about Islam from the sources of literalist, radical groups and later naturalized this literalist perception of Islam because of the lack of other/ alternative information and religious education venues. In other words, a great majority of those who are entrapped by literal, radical ideas found this kind of knowledge as their first systematic Islamic knowledge. ${ }^{14}$ In particular, young Central Asian Muslims searching for Islamic knowledge can easily encounter 'literalist' interpretations on the Internet and in bookstores, or may

Radical Muslims in postSoviet Central Asia at the very beginning were faced with information about Islam from the sources of literalist, radical groups and later naturalized this literalist perception of Islam because of the lack of other/alternative information and religious education venues. get them from relatives, colleagues, or friends during the hajj pilgrimage. The information provided by the 'Muftiyat' of Kazakhstan (or DUMKa) ${ }^{15}$ and the 'Muftiyat' of Kyrgyzstan (or DUMKy) ${ }^{16}$ were insufficient despite many positive changes that have been made recently. To sum up, after the 2000s, in Kazakhstan and Kyrgyzstan, it became common that the first Islamic knowledge for those learning Islam was in a literalist format which can lead under certain conditions to radicalism.

\footnotetext{
${ }^{13}$ Kozyrev, Timur, 'In the Islamic sphere the serious identional struggle is unfolding', http://www.zakon.kz/interviews/4543537-timur-kozyrev-na-islamskom-pole.html; Satpayev, Dosym, 2013. "Terrorism in Kazakhstan", Forbes Kazakhstan, 20 June 2013, http://forbes.kz/process/expertise/terrorizm_v_kazahstane_vremya_sobirat_kamni_za_ pazuhoy

${ }^{14}$ Interview by the author of an anonymous member of the executive staff of the Kazakhstan Muftiyat, anonymous imams and instructors of Islamic University "NurMubarek" in Almaty

15 DUMK (In Russian, Duhovnoye Upravleniye Musulman Kazakhstana) denotes the 'Spiritual Administration of Kazakhstan Muslims, representing the Muslims of the Hanafi School.

${ }^{16}$ DUMK (In Russian, Duhovnoye Upravleniye Musulman Kyrgyzstana) denotes the 'Spiritual Administration of Kyrgyzstan Muslims', representing the Muslims of the Hanafi School.
} 
The Muftiyats of both countries could not meet the demands of Muslims for education, and the primary reason was lack of funding. Since independence, both Muftiyats have relied on foreign funding, private local funding, and various donations. This situation eventually constituted a logistical base for the success of literalist radicals at the expense of the conventional and moderate Hanafi School. The insufficient outlets for religious education and a lack of well-educated imams paved the way for foreign-educated (predominantly in some Middle Eastern countries) theology students who embraced literalist methodology. A majority of imams serving in the mosques controlled by the Muftiyats did not receive formal religious education. In this case, the foreign-trained 'literalist' preachers were met with enthusiasm by the young generation, which is greatly interested in Islam and is not impressed by their local imams and other members of the Muftiyats. All in all the 'Muftiyats' (DUMKs) representing the adherents of the conventional Hanafi School became 'uncompetitive' and needed state support to tackle the massive assault of different 'literalist' groups. In the meantime, the literalist and, much worse, radical interpretations of Islam were being intensively disseminated on the Internet and no state organ could officially control this issue. Only in recent years did the Muftiyats of Kazakhstan and Kyrgyzstan, and the Central Mosques of Almaty and Astana, begin providing relatively high-quality and timely information about Islam on the Internet.

\section{Kazakhstan's Recently Adopted Anti-Radicalism Policy}

The terrorist acts committed in different regions of the country in 20102011 became a turning point for Kazakhstan. Ultimately the Kazakh government began fighting against extremist groups using different methods. The leading method was tightened control over religious organizations and the promotion of conventional mazhabs (foremost Hanafi) doctrines among local Muslim communities. In place of the law adopted in 1992, a new one strengthening the position of official organs and state control over religious organizations was adopted in September 2011. The drafting process and subsequent adoption of the law generated heated debates on state-religion relations in the country. According to the new law, all religious organizations must be registered by the state after their missions and teachings have been scrutinized (see appendix).

In the preamble to the law, the importance of the Hanafi School in the history and culture of Kazakhstan is emphasized. The wording of the law indicates that the Muftiyat (DUMKa), which relies on the doctrine of the Hanafi School, represents the Muslim community of Kazakhstan. But, on 
the other hand, no religion or school is given priority or special status; in this respect, the new law is quiet democratic ${ }^{17}$. It would be incorrect to assume that the Muftiyats in Kazakhstan (DUMKa), and more absurdly in Kyrgyzstan, have assumed the same function as the Soviet-era 'religious boards of Muslims (SADUM).' DUMKs cannot be presented as 'state' organizations, not to mention the fact that they are not 'public' institutions, in fact they are civil society institutions. When necessary DUMKs can openly defend their own doctrinal positions against the views of officials. For instance, while in recent years some Kazakh officials offered critical views concerning Muslim women's headscarves (hijabs), the Kazakh DUMK adopted a special fatwa defending the hijab and the inviolability of the right to wear it ${ }^{18}$. Similarly, during the debates preceding the adoption of the new law on religious organizations, the Actually the larger Kazakh DUMK and leading imams problem faced by postSoviet Central Asian countries is how to build a passive, human rights-friendly secularism, while controlling religious radicalism. On the whole, tightened state control over religious organizations and 'semi-official preference' of the Hanafi doctrine over 'literal' teachings should be seen as an emergency/last vigorously defended their doctrinal views. For instance, the current imam of Astana Hazret Sultan Mosque (who previously served in the DUMK administration) extensively debated with the Head of The Agency for Religious Affairs on the Internet and in other media outlets over some issues. The former Grand Mufti was also engaged in the discussions with officials over some regulations included in the new bill.

Actually the larger problem faced by post-Soviet Central Asian countries is how to build a passive, ${ }^{19}$ human rightsfriendly secularism, while controlling religious radicalism. On the whole, tightened state control over religious organizations and 'semi-official resort. preference' of the Hanafi doctrine over 'literal' teachings should be seen as an

\footnotetext{
${ }_{17}$ For the text of the law, visit http://www.zakon.kz/4453758-o-religioznojjdejatelnosti-i.html

18 The Kazakh Muftiyat issued a fatwa defending hijab and Muslims on the website of Almaty Central Mosque, 21 March 2013, http://azan.kz/article/show/id/2420.html ${ }^{19}$ Ahmet T. Kuru classified secularisms as 'assertive' versus 'passive' or 'combative' versus 'pluralistic'. 'Assertive' secularism excludes religion from the public sphere and confines it to the private domain, whereas 'passive' secularism allows for the public visibility of religion, see Kuru, Ahmet, 2007. "Passive and Assertive Secularism. Historical Conditions, Ideological Struggles and State Policies towards Religion," World Politics, No 59.
} 
emergency/last resort. In essence this policy is supposed to be temporary, because after regaining strength or at least gaining equal opportunities to compete with literalist interpretations, the Hanafi School will not need any backing by the state. ${ }^{20}$ Furthermore, 'excessive' control by the state and prolonged state support will inevitably harm the Hanafi community itself, as it will prevent them from 'natural/ indigenous' development.

However, under current conditions the state should provide opportunities for Muslims to receive a proper religious education premised upon tolerance, acceptance of diversity, gradualness in religious teaching, and inculcating a sense of positive action in the minds and hearts of Muslims.

\section{It must be underlined that the state's policy of controlling the field of religious life with the aim of fighting religious radicalism and the 'semi-official' preference of the Hanafi School must not lead to establishing 'state Islam' or securitization of Islam.}

It must be underlined that the state's policy of controlling the field of religious life with the aim of fighting religious radicalism and the 'semi-official' preference of the Hanafi School must not lead to establishing 'state Islam' or securitization of Islam. Recent history shows that in countries with oppressive political regimes, the ruling elites adopted a wholesale approach to fighting terrorism and justified crackdowns on every view, group, or power perceived as 'alternative' within the framework of 'anti-terrorist measures.' Moreover, the most oppressive regimes in Muslim countries adopted an extremely combative Jacobean understanding of secularism and even embarked on 'securitization' of Islam. 'Securitization,'

or 'threat construction,' signifies a discursive practice of defining a phenomenon that does not necessarily belong to a security realm as a security threat. ${ }^{21}$ On the whole, we hope that the recent policy shift in Kazakhstan and Kyrgyzstan (Tajikistan also wants to regulate religious life in the country so as to curb the spread of radicalism) are not precursors of imposing 'assertive secularism' (in place of practically developing 'passive secularism') or securitization of Islam.

\footnotetext{
${ }^{20}$ In general political and religious pluralism inevitably curbs radicalism as the competitive market of religious ideas obliges religious figures to moderate their discourse (Bilgin, Fevzi, Political Liberalism in Muslim Societies, London: Routledge, p.110).

21 Omelicheva, Mariya, 2011. "Islam in Kazakhstan: a survey of contemporary trends and sources of securitization”, Central Asian Survey, Vol.30, No 2, p. 244.
} 
Similar to what has been suggested concerning 'conventional' Muslim societies (in a sense the societies which did not experience the threegeneration-long atheistic period), ${ }^{22}$ we can argue that if the political establishments in post-Soviet states refrain from secularist policies and secure religious liberties, religion (Islam) will withdraw from the political scene, since "the more religion is threatened by hostile secularism the more political religion becomes". ${ }^{23} \mathrm{All}$ this means the necessity of adoption of 'passive secularism' by the political establishments of Central Asian states. Nonetheless, since Central Asian societies had undergone forceful indoctrination in atheism, an additional variable such as 'state-supported conventional religious education antithetical to radicalism' needed to be added.

\section{Conclusions and Recommendations}

The fundamental policy shift from almost total indifference towards religious groups in the 1990 s and early 2000 s to more tightened state control and 'semi-official' preference of a particular religious group in Kazakhstan and Kyrgyzstan tended to be interpreted negatively in the West. For instance, the new law enacted by Kazakhstan was criticized by many for being anti-democratic, unnecessarily restricting the freedom of religion, and contradicting the underlying principles of secularism.

It needs to be underscored that this tightened control over the religious sphere and semi-official backing of the Hanafi School should be seen as a policy limited in time and aimed at upgrading the competitiveness of the conventional, moderate methodology of interpretation of Islam, which is the only antidote to radicalism in the region.

Whereas some cases of violations of human rights cannot be dismissed, on the whole the strategy of curbing the spread of religious radicalism may be considered successful. The new law adopted by Kazakhstan, despite of some of its deficiencies, has played a considerable role in decreasing the threat posed by different radical groups. For instance, a number of websites transmitting radical ideas were closed or blocked, and many books containing radical ideas were confiscated. It was surprising that such literature was sold freely in many bookstores and even found in prisons. However, these measures should not divert attention from the protection of human rights and developing democracy.

22 Bilgin, p .65

${ }^{23}$ Bilgin, p. 59 
Muslims in Central Asia must strive to provide proper religious education, which is now in a dire state, and must reform the nondynamic centers/institutions of Islamic education infiltrated by the literalists which became 'frozen' in the past. It is expected that Islam will continue shaping individual and public life in Central Asia. Thus, it is necessary to nurture in post-Soviet Central Asia the methodology and understandings of 'enlightened and ethical' Islam. Locally organized, viable and dynamic Islamic education has to be generously supported by donors and legally protected from ideological (especially by 'literalists') incursions. Under current conditions in post-Soviet Central Asia this kind of support can be provided only by the state. However, in the future any kind of support to the religious education system must be provided by civil society.

\section{Muslims in Central \\ Asia must strive to \\ provide proper \\ religious education, \\ which is now in a dire \\ state, and must \\ reform the non- \\ dynamic \\ centers/institutions of \\ Islamic education \\ infiltrated by the \\ literalists which \\ became 'frozen' in the \\ past.}

The current tightened control over the religious sphere and semi-official backing of the Hanafi School should be in essence a temporary measure, enabling it to compete with literalist radical interpretations. The revitalization of the Hanafi understanding of Islam is expected to bring about comprehensive social innovation and repair the 'shaken identity' (one of the leading reasons for the spread of radicalism) of Central Asian Muslims struggling with both the toxic legacy of the Soviet period and complex crises of the period of transition. It will also help diminish interethnic and intercommunal tensions and conflicts, which concern many states in the region since the last years of the Soviet Union.

To conclude, Central Asian people can rediscover the dynamics which gave birth to the glorious Central Asian civilization that flourished one millennium ago in their very lands if 'enlightened and ethical' Islam based upon the Hanafi School's doctrine is revitalized and the experience of faith-based civic initiatives and movements originating in other countries (primarily in Turkey, Malaysia, and Indonesia) is adopted.

Last but not least, conscious adherence to the Hanafi School would prevent Muslims from being drawn into politicization of Islam (instrumentalization of Islam in politics), which essentially de-sacralizes and impoverishes Islam and even threatens its survival as a transcendental religion. However, in a society with an already diversified social fabric, with established strong political and legal 
institutions, a market economy and an internalized sense of the 'rule of law' and human rights, 'Muslim politics'24 might be seen as an acceptable form of political expression.

${ }^{24}$ By "Muslim politics" Ahmet T. Kuru means "politics conducted by pious Muslims who consciously seek to reflect their Islamic values and principles without pursuing the idea of an Islamic state", see Kuru, Ahmet, 2003. Muslim Politics Without an 'Islamic' State. Brookings Doha Center, Policy Briefings, February, p.10. 


\section{Appendix}

\section{Summary of the Kazakhstan's "Law on Religious Activity and Religious Associations" (11 October 2011)}

The Law is based on the fact that the Republic of Kazakhstan establishes itself as a democratic secular state that affirms the right of everyone to freedom of conscience; guarantees the equality and rights of everyone regardless of her/his religious beliefs; recognizes the historical role of the Hanafi school of Islam and Orthodox Christianity in the development of culture and spiritual life of the people of Kazakhstan; respects other religions which are in accord with the spiritual heritage of the people of Kazakhstan; and recognizes the importance of inter-religious harmony, religious tolerance, and respect for religious beliefs of citizens.

According to the Law, the state is separated from religion and religious associations.

Religious associations and citizens of the Republic of Kazakhstan, foreigners, and stateless persons irrespective of religion are equal before law.

No religion can be established as a state religion or as obligatory.

The system of education in the Republic of Kazakhstan, with the exception of the institutions of religious education, is separated from religion and religious organizations and it is of secular character.

Prevention of legitimate religious activities, violation of civil rights of individuals based on their attitudes to religion or insulting religious feelings, desecration of the objects, buildings or places esteemed by religious believers are not allowed.

Everyone has the right to have religious or other beliefs, disseminate them, to participate in the activities of religious associations, and engage in missionary activity in accordance with the legislation of the Republic of Kazakhstan.

Nobody has the right based on her/his religious beliefs to refuse to perform the duties prescribed by the Constitution and laws of the Republic of Kazakhstan. 
Citizens of the Republic of Kazakhstan, who are priests, missionaries, leaders or participants (members) of religious associations can participate in the political life on an equal basis with all other citizens of the Republic of Kazakhstan, but only on her/his own behalf.

In accordance with the principle of separation of religion and religious associations from the state, the state

(1) shall not interfere in determining/defining a citizen of the Republic of Kazakhstan, foreigners and stateless persons of her/his attitude to religion and her/his religious affiliation; the education of children by their parents or by other legal representatives in accordance with their convictions, except in cases where such education threatens life and health of a child, infringes her/his rights and limits her/his liability, and if directed against the constitutional order, sovereignty and territorial integrity of the Republic of Kazakhstan;

(2) shall not entrust religious communities with a task to fulfill/execute the functions of the state institutions;

(3) shall not interfere in the activities of religious organizations, if the activities of religious associations are not contrary to the laws of the Republic of Kazakhstan;

(4) shall promote mutual tolerance and respect between the citizens of the Republic of Kazakhstan, foreigners and stateless persons, those who profess any religion or not, as well as between different religious communities.

In accordance with the principle of separation of religion and religious associations from the state, religious associations:

(1) shall not perform the functions of the state institutions and shall not interfere in their activities;

(2) shall not participate in the activities of political parties, shall not provide financial support to them, shall not engage in political activity;

(3) shall be obliged to comply with the legislation of the Republic of Kazakhstan;

Political parties based on religion, religious organizations whose goals and activities are aimed at establishing the supremacy of a particular religion or inciting religious hatred and discord, including those which 
entail violence or incitement to violence and other illegal activities, are prohibited.

Religious associations that are not registered in accordance with the laws of the Republic of Kazakhstan, as well as those that are involved in coercion of citizens of the Republic of Kazakhstan, foreigners, and stateless persons in determining of their attitude to religion; coercion to participate or not participate in the activities of religious associations, religious ceremonies and (or) religious education, are not allowed.

The activities of religious associations which entail violence against the citizens of the Republic of Kazakhstan, foreigners and stateless persons; or inflict harm to their health by other means; or lead to termination of a marriage between spouses (family breakdown), or lead to termination of kinship; or cause damage to public morality and ethics; or violate the rights and freedoms of individual and citizen; or incite citizens to refuse to perform the duties prescribed by the Constitution and laws of the Republic of Kazakhstan; and involve other violations of the legislation of the Republic of Kazakhstan, are not allowed.

The activities of religious associations that force the citizens of the Republic of Kazakhstan, foreigners, and stateless persons against their free will, including through charitable activities; and (or) which prevent the exit from the religious community, including through the use of blackmail, violence or threat to intimidate, or manipulation of the material or other dependence of the citizens of the Republic of Kazakhstan, foreigners and stateless persons; or deception, are not allowed.

The coercion of the participants (members) of religious association and religious followers to the alienation of their property for the benefit of the religious association, its leaders and other participants (members), is not allowed.

The use of religion or religious views with the deliberate aim to sabotage the functioning of state institutions or disrupt their smooth functioning, or cause damage to the governance of the country, is not allowed.

The head of a religious association is obliged to take measures to prevent the involvement and (or) the participation of underage in the activities of the religious association, if one of her/his parents or other legal representatives objects. 


\section{About the Author}

Dr. Galym Zhussipbek is a faculty member at Department of International Relations, Suleyman Demirel University, Almaty, Kazakhstan. He also works as an analyst in several research institutions. He received $\mathrm{BA}, \mathrm{MA}$, and $\mathrm{PhD}$ (2008) in international relations from Ankara University. Dr. Zhussipbek's main research interests are European security, security in the post-Soviet region, economic, social and religious situation in Central Asia, state-religion relations. 